\title{
Nasopharyngeal Cancer Pathologic Regional Lymph Nodes TNM Finding v6
}

National Cancer Institute

\section{Source}

National Cancer Institute. Nasopharyngeal Cancer Pathologic Regional Lymph Nodes

TNM Finding v6. NCI Thesaurus. Code C64472.

A pathologic finding about one or more characteristics of nasopharyngeal cancer, following the rules of the TNM AJCC v6 classification system as they pertain to staging of regional lymph nodes. 